\title{
PERIPHERAL NERVE REGENERATION: CELL THERAPY AND NEUROTROPHIC FACTORS
}

Alessandra Deise Sebben', Martina Lichtenfels ${ }^{2}$, Jefferson Luis Braga da Silva ${ }^{3}$

\section{ABSTRACT}

Peripheral nerve trauma results in functional loss in the innervated organ, and recovery without surgical intervention is rare. Many surgical techniques can be used for nerve repair. Among these, the tubulization technique can be highlighted: this allows regenerative factors to be introduced into the chamber. Cell therapy and tissue engineering have arisen as an alternative for stimulating and aiding peripheral nerve regeneration. Therefore, the aim of this review was to provide a survey and analysis on the results from experimental and clinical studies that used cell therapy and tissue engineering as tools for optimizing the regeneration process. The articles used came from the LILACS, Medline and SciELO scientific databases. Articles on the use of stem cells, Schwann cells, growth factors, collagen, laminin and platelet-rich plasma for peripheral nerve repair were summarized over the course of the review. Based on these studies, it could be concluded that the use of stem cells derived from different sources presents promising results relating to nerve regeneration, because these cells have a capacity for neuronal differentiation, thus demonstrating effective functional results. The use of tubes containing bioactive elements with controlled release also optimizes the nerve repair, thus promoting greater myelination and axonal growth of peripheral nerves. Another promising treatment is the use of platelet-rich plasma, which not only releases growth factors that are important in nerve repair, but also serves as a carrier for exogenous factors, thereby stimulating the proliferation of specific cells for peripheral nerve repair.

Keywords - Peripheral Nerve System/injuries; Regenerative Medicine; Nerve Regeneration

\section{INTRODUCTION}

Peripheral nerve transection traumas are extremely common in clinical practice and recovery without surgical intervention is rare. Lesions with loss of nerve substance produce serious problems for the patient. Besides causing pain and morbidity, these injuries usually generate permanent sequelae, such as sensory deficit and functional dysfunction. These lesions cause damages that substantially diminish the quality of life of these patients, including physical disability and total or partial loss of their productive activities, which gives rise to important social and economic consequences $^{(1)}$. The current repair techniques offer random and frequently unsatisfactory results. In view of these limitations, many researchers seek therapeutic options to improve the repair of lesions with peripheral nerve transections ${ }^{(2)}$.

Nowadays autologous peripheral nerve transplantation represents the gold standard of repair when there is loss of substance that precludes neurorrhaphy. However, it presents some limitations, such as the need to perform two surgical procedures at different sites, the consequent greater morbidity and the shortage of nerve donor sites, besides the resulting sensory deficit in the area from which it was removed ${ }^{(2,3)}$.

In cases where the extent of the lesion precludes the simple joining of the stumps, an available and widely used repair technique is tubulization. This technique,

\footnotetext{
1 - Biologist, Studying towards Doctoral Degree in Medicine and Health Sciences (PUCRS) - Porto Alegre, RS, Brazil.

2 - Biologist, Studying towards Master's Degree in Medicine and Health Sciences (PUCRS) - Porto Alegre, RS, Brazil.

3 - Physician; Full Professor of the School of Medicine (PUCRS) - Porto Alegre, RS, Brazil.

Study conducted at the Laboratory of Medical Abilities and Surgical Research, Pontifícia Universidade Católica do Rio Grande do Sul - PUCRS

Mailing address: Avenida Ipiranga, 6.690 / 64, Partenon - 90610-000 - Porto Alegre, RS. Email: adsebben@gmail.com

Study received for publication: 2/11/2011, accepted for publication: 6/16/2011.
}

The authors declare that there was no conflict of interest in conducting this work 
also called entubulation, is a surgical procedure in which the sectioned nerve stumps are introduced and fastened inside a tubular prosthesis, aiming to provide a favorable environment for regeneration. It also serves as a guide for the nerve growth of the broken or sectioned ends ${ }^{(2,4)}$, protecting the nerve fibers of the scar tissue and avoiding neuroma formation ${ }^{(5)}$. Tubulization presents another interesting characteristic: it can be optimized with the addition of regenerative factors $^{(6-8)}$.

It is known that tissue repair requires a complex interaction between cells, extracellular matrix and trophic factors, which are all important elements involved in nerve regeneration ${ }^{(9)}$. Consequently, cell therapy and tissue engineering have been receiving a great deal of attention in recent decades, and are widely used in different areas ${ }^{(7,10-13)}$.

Although the complexity of molecular and cellular events of tissue repair is not yet completely clarified, existing knowledge of the mechanisms of the cascade that induces regeneration after peripheral nerve lesions is vast, and provides important information for a better conception of nerve repair. Therefore, the aim of this review is to provide a survey and analysis of experimental and clinical studies regarding the results obtained from peripheral nerve repair techniques, which use cell therapy and tissue engineering as tools to optimize the regeneration process. The articles used are from scientific databases LILACS, Medline and SciELO.

\section{REVIEW OF LITERATURE}

\section{Cell therapy and peripheral nerve repair}

Cell transplantation is one of the cell therapy and tissue engineering strategies aimed at the creation of a favorable microenvironment for tissue regeneration. Stem cells have important characteristics that differentiate them from other cell types, are undifferentiated precursor cells that have self-renewal ability and can differentiate into multiple lineages ${ }^{(14)}$. They are present in several tissues and are responsible for their regeneration in the event of injuries or lesions ${ }^{(15)}$. Bone marrow, adipose tissue, umbilical cord blood and peripheral blood are some sources of stem cells; however, these cells can be tissuespecific, i.e., originating directly from specialized tissues $^{(6,14,16-18)}$. In nerve repair, the most widely used cells include the mesenchymal cells of the bone marrow and of the adipose tissue, as well as the actual Schwann cells ${ }^{(6,7,19-33)}$ (Table 1).

These cells can be applied directly after density gradient separation (Ficoll-Paque ${ }^{\circledR}$ ) or be cultivated and differentiated in vitro for subsequent application, as is the case of stem cell differentiation into Schwann cells. We present below a description of some of the cell types used most often in nerve repair surveys.

Table 1 - Types of cells used as cell therapy in nerve repair.

\begin{tabular}{l|c|c}
\multicolumn{1}{c|}{ Cell } & Study model & Reference \\
\hline $\begin{array}{l}\text { Bonemarrow-derived } \\
\text { mesenchymal }\end{array}$ & Clinical & 7 \\
\hline $\begin{array}{l}\text { Bonemarrow-derived } \\
\text { mesenchymal }\end{array}$ & Experimental & $\begin{array}{r}6,19,20,21,22, \\
23,24\end{array}$ \\
\hline $\begin{array}{l}\text { Adipose-derived } \\
\text { mesenchymal }\end{array}$ & Experimental & 25,26 \\
\hline & & $27,28,29,30,31$, \\
Schwann cells & Experimental & 32,33 \\
\hline
\end{tabular}

\section{Schwann cells in nerve repair}

The cells most commonly used in nerve regeneration are autologous Schwann cells (SC). These represent glial cells in the peripheral nervous system, and their main function is to provide support to the axons through the release of growth factors and isolation of the axon through formation of the myelin sheath $^{(34)}$. The addition of SCs in synthetic tubes assists regeneration in nerve defects, although repair with autologous graft, in most studies, still presents superior recovery ${ }^{(27,29,33,35-37)}$. Besides synthesizing growth factors, SCs also are able to produce extracellular molecules, such as laminin and type IV collagen. The extracellular matrix can serve as a reservoir of growth factors that are secreted by SCs ${ }^{(38)}$.

Experimental studies based on the use of SCs as a therapeutic option for the recovery of nerves with loss of substance proved the efficacy of these cells $^{(28,32,39)}$. SCs play an important role in the maintenance, nutrition and in the repair of peripheral nerves. Although there are still limiting factors in the use of SCs, these have promising results in tissue, physiological and functional improvement in 
lesions caused by trauma or pathologies in peripheral nerves.

\section{Bone marrow mesenchymal cells and nerve rege- neration}

Many researchers have developed studies on stem cells ${ }^{(19,25,27,40)}$. Embryonic stem cells, as well as those obtained from adult cerebral tissue, are able to undergo expansion and neuronal differentiation in vitro and in vivo. However, the inaccessibility of these cells limits their clinical use, which stimulated the search for cells that are capable of differentiating into neuronal lineages ${ }^{(28,41)}$. Moreover, there is controversy involving research with the use of stem cells concerning the sources from which these are obtained. In particular, the use of embryonic stem cells, although legally regulated in Brazil, allowing research into and the manipulation of these cells obtained through "unviable embryos", is still a subject of ethical and political discussions ${ }^{(29,30,42,43)}$.

An alternative and viable source of mesenchymal stem cells is bone marrow. Adult bone marrow-derived cells are characterized as multipotent, as they are able to differentiate into cell lineages of mesodermal ori$\operatorname{gin}^{(44,45)}$. Several surveys on transplantation of bone marrow-derived mesenchymal stem cells (BMDMSC) have reported that these cells also present in vitro neuronal differentiation ability, which means they can be used in peripheral nerve repair ${ }^{(46-52)}$. Additionally, Montzka et $\mathrm{al}^{(53)}$ demonstrated the ability of human BMDMSCs to express different neuronal and glial cell markers.

Experimental studies in rodents ${ }^{(20,21,23)}$, rabbits $^{(22,54)}$ and primates ${ }^{(55)}$ prove the efficiency of these cells, presenting positive functional outcomes in peripheral nerve repair. The combination of bone marrow mesenchymal cells with bioabsorbable tube increases nerve regeneration and sciatic nerve functional recovery in mice ${ }^{(56)}$. BMDMSCs can positively influence the regeneration of peripheral nerves not only through the direct release of neurotrophic factors, but also through indirect modulation of the behavior of SCs ${ }^{(24,46)}$.

There is clinical evidence indicating BMDMSCs as an effective treatment in peripheral nerve repair. In comparing the tubulization technique with and without the addition of bone marrow mononuclear cells (this group of cells contains a fraction of stem cells) in 44 patients with damage to the median or ulnar nerve, it was verified that lesions treated with these cells presented better results in the regeneration process than conventional tubulization ${ }^{(7)}$.

However, BMDMSCs present some limitations. Besides the fact that these cells are obtained with the application of epidural or general anesthesia, since harvesting occurs through a very painful procedure, the quantity of cells acquired often fails to reach the necessary number ${ }^{(57)}$.

\section{Adipose tissue-derived mesenchymal cells and ner- ve regeneration}

Mesenchymal stem cells are not only present in the bone marrow, but also in other tissues including the adipose tissue ${ }^{(18)}$. Most authors call them adipose-derived stem cells, or ADSCs.

There is a strong resemblance between ADSCs and BMDMSCs, since both present a similar immunophenotypical profile, as well as the ability to differentiate into osteogenic, chondrogenic, myogenous and adipogenic lineages ${ }^{(58,59)}$. The advantage of using ADSCs is their widespread availability, as human subcutaneous fat is abundant, and can be harvested easily through the liposuction procedure, besides the fact that it appears much more frequently in the adipose tissue than mesenchymal cells in the bone marrow ${ }^{(60)}$.

The ability of mesenchymal cells originating from the adipose tissue to differentiate into cells with neuronal features was proved in vitro. Kingham et $\mathrm{al}^{(61)}$ reported that ADSCs are able to differentiate into cells similar to the genuine SC, when cultivated together with a combination of glial trophic factors.

Cells derived from adipose tissue of murinae and humans, after neuronal induction, presented morphology typical of nerve cells, which were positive for immunocytochemical expression of GFAP, nestin and neuron-specific nuclear protein (Neu-N). Pre-treatment with epidermal growth factor (EGF) and basic fibroblast growth factor (FGF) increases the neuronal differentiation of adipose-derived human stem cells, whose use has important biological and clinical implications ${ }^{(41)}$. However, the adipose-derived mesenchymal stem cell should have the ability to produce myelin sheath, the main function of SCs. This characteristic was confirmed in in vitro studies, thus becoming another option for the treatment of peripheral nerve injuries ${ }^{(57)}$.

The adipose-derived mesenchymal stem cells present results similar to bone marrow-derived cells in vivo $^{(25,26)}$. However, due to the ease of their harvesting 
and abundant quantity of cells available in subcutaneous deposits, ADSCs are indicated as a better alternative for clinical application ${ }^{(25)}$.

\section{Growth factors in nerve repair}

The complexity of nerve regeneration involves a range of elements that interact with one another, and are all essential to the process; among them, the growth factors (GF) aroused a great deal of interest in the scientific community ${ }^{(62)}$, due to their performance as important cell modulators ${ }^{(62-78)}$ (Table 2 ).

Degenerated peripheral nerves are an important source of these factors, as are the SCs. These proteins are basically a set of three families of molecules and their receptors, responsible for maintaining the growth and survival of the sensory and motor axons and neurons after tissue damage ${ }^{(62)}$.

The local presence of GFs is important in the control of the survival, migration, proliferation and differentiation of various types of cells that are engaged in nerve repair ${ }^{(9,62)}$. For these reasons, the use of therapies based on GFs has increased in the last few decades. Growth factors should be administered locally to achieve a more adequate therapeutic effect with few adverse reactions. Therefore, the delivery of growth factors for nerve regeneration can be ideally combined with nerve conduits ${ }^{(34)}$.

Among neurotrophic factors, the nerve growth factor (NGF) is the most researched factor, due to its action in the proliferation and differentiation of neurons ${ }^{(64)}$ and as it assists in the repair and functional recovery of injured nerves ${ }^{(63)}$. When combined with biomaterials and with controlled release, its effect can

Table 2 - Main neurotrophic factors used in peripheral nerve repair.

\begin{tabular}{c|l|c}
\hline Growth factor & \multicolumn{1}{|c}{ Main target } & Reference \\
\hline NGF & $\begin{array}{l}\text { Sensory neurons and small } \\
\text { axons }\end{array}$ & $63,64,65$ \\
\hline BDNF & $\begin{array}{l}\text { Sensory neurons and large } \\
\text { axons }\end{array}$ & $66,67,68$ \\
\hline NT-3 & Sensory and motor neurons & 69 \\
\hline NT-4/5 & Motor neurons & 62 \\
\hline GDNF & Motor neurons & 70 \\
\hline CNTF & Sciatic nerve & 71 \\
\hline IGF & $\begin{array}{l}\text { Inflammatory (anti-inflammatory) } \\
\text { cells; sensory and motor } \\
\text { neurons }\end{array}$ & $72,73,74,75$ \\
\hline VEGF & Vascular endothelial cells & $76,77,78$ \\
\hline
\end{tabular}

be strengthened ${ }^{(79-81)}$. The ability of the NGF to promote functional recovery after lesions was confirmed in experimental studies ${ }^{(65,81)}$.

The endogenous brain-derived neurotrophic factor (BDNF) demonstrates an important role in the induction of the cell body response in injured rat neurons. When exposed to mitogens such as BDNF, stem cells differentiate into neuronal lineages in vitro ${ }^{(68)}$.

The glial cell line-derived neurotrophic factor (GDNF) is considered the most protective factor for motor neurons $^{(70)}$, and is essential in their formation, as well as that of sensory neurons during the regeneration process ${ }^{(82)}$. GDNF has its expression elevated in experimental models of motor neuropathies in rats, several human neuropathies and in traumatized human nerves ${ }^{(82)}$. In a model of peripheral nerve lesion in rats, it was demonstrated that the combination of nerve conduits composed of chitosan, GDNF and laminin was significantly more efficient during the initial stages of nerve repair, promoting greater axonal growth and myelination in six weeks after the animals' nerve transection ${ }^{(83)}$.

The ciliar neurotrophic factor (CNTF) assists in the differentiation and in the survival of a variety of neurons, and the mRNA expression levels of CNTF decrease significantly and continue low for a long time after peripheral nerve transection ${ }^{(71)}$.

Similarly, the insulin-like growth factor (IGF) also assists in nerve regeneration. IGF-1 is present in several stages of development of the peripheral nerve system, performing a wide range of functions, including the promotion of the regeneration of motor and sensory axons ${ }^{(72-75)}$. Evidence suggests that high levels of IGF in denervated muscle can stimulate regeneration with nerve sprouting ${ }^{(84)}$.

Besides acting essentially in the vascular tissue, the vascular endothelial growth factor (VEGF) also assists nerve regeneration, due to the close relationship existing between the nerve fibers and the blood vessels during this process. The addition of VEGF significantly increases the infiltration of blood vessels in nerve conduction chambers, and is related to the increase of axonal regeneration and migration of SCs ${ }^{(76,77)}$. Moreover, the VEGF acts as a neuroprotective agent in neurons in vitro after ischemic lesion $^{(78)}$. In an experimental study, 
the use of VEGF demonstrated an effect on vascular blood supply, with a significant increase of axonal regeneration and of SCs, stimulating nerve regeneration $^{(85)}$.

\section{Collagen and laminin as carriers}

Components of the extracellular matrix are collagen and laminin, essential for guidance and axonal growth during the nerve regeneration process. Collagen and laminin are involved in the regeneration process through the formation of a substrate for the migration of non-neuronal cells. The filling of silicone tubes with these components presents an increase in the regeneration rate ${ }^{(86)}$ and in the connection of extensive defects ${ }^{(87)}$. This effect, however, depends on some factors such as the concentration and permeability of the tube ${ }^{(87,88)}$.

Nowadays, different gels containing collagen or laminin (Matrigel ${ }^{\circledR}$ ) are being used as a support for cells and growth factors ${ }^{(27,35,37)}$. Collagen, as the main component of the extracellular matrix, is used in various surgical prostheses. A study on an animal model demonstrated the efficacy of a biological matrix composed of collagen (Tissudura ${ }^{\mathrm{TM}}$ ) when used in nerve regeneration ${ }^{(89)}$.

As is the case of collagen, laminin also plays an important role in in vivo axonal growth. Surveys include this component of the extracellular matrix in animal models to repair injured sciatic nerves and to obtain an improvement in some areas of axonal regeneration. The application of tubes composed of chitosan combined with laminin demonstrates that the tube optimizes the nerve regeneration process during the initial phases of repair ${ }^{(83)}$.

\section{Use of platelet-rich plasma in peripheral nerve repair}

Autologous blood-derived platelet-rich plasma (PRP) is defined as a volume of plasma with platelet concentration around five times above the physiologic levels ${ }^{(90)}$. The platelets that constitute PRP are able to release various growth factors that are essential for the healing of lesions, such as the three platelet growth factor isomers (PDGF $\alpha \alpha, \beta \beta$ and $\alpha \beta$ ), VEGF, transforming growth factor (TGF- $\beta 1$ $\beta 2)$ and epithelial growth factor $(\mathrm{EGF})^{(91,92)}$. The platelets are also responsible for the synthesis and storage of $\mathrm{BDNF}^{(93)}$.

PRP has been used by areas such as oral and bu- comaxillofacial surgery for some time ${ }^{(94-96)}$, and it has aroused considerable interest in cosmetic ${ }^{(97,98)}$ and orthopedic $^{(99,100)}$ surgery. In experimental studies, PRP was used in peripheral nerve lesions, promoting remyelination in the facial ${ }^{(91)}$ and sciatic nerve of rats ${ }^{(8)}$.

The application of PRP increases the number of nerve fibers after peripheral nerve lesions, and can produce a neurotrophic effect, stimulating the proliferation of Schwann cells and myelination, important components during peripheral nerve repair ${ }^{(6,101)}$.

Data in literature on the effect of PRP on peripheral nerve regeneration are scarce, which stimulates the search for more precise information about its performance. Therefore, this treatment should receive attention and be expanded, as it has the potential to become another safe option of low associated cost for the treatment of a wide variety of lesions and neuropathies in peripheral nerves.

\section{CONCLUSION}

The concept of an ideal treatment to assist in nerve repair is based on the creation of synthetic tubes, preferentially bioabsorbable, covered by components of the extracellular matrix and that are appropriate for controlled release of one or more neurotrophic factors, bioactive elements or cells. The combination of two or more growth factors probably has a synergic effect on nerve regeneration, especially when they belong to different families and act by distinct mechanisms. In spite of the vast knowledge already acquired about these proteins in the improvement of nerve regeneration, more experimental studies are necessary before their use in clinical practice.

The use of cells, whether actual Schwann cells or the stem cells obtained from varied sources, demonstrates considerable benefits in the repair of peripheral nerves, with great potential to become one of the most promising options at the clinic.

Another interesting technique that has not yet been fully explored is the use of PRP, which releases autologous growth factors and serves as a carrier for other exogenous factors in nerve regeneration.

Considering the evidence found, it was observed that a promising treatment is based on the combination of biological and synthetic elements for regeneration to be optimized and to provide better results. 


\section{REFERENCES}

1. Noble J, Munro CA, Prasad VS, Midha R. Analysis of upper and lower extremity peripheral nerve injuries in a population of patients with multiple injuries. $J$ Trauma. 1998;45(1):116-22.

2. Oliveira A, Pierucci A, Pereira K. Peripheral nerve regeneration through the nerve tubulization technique. Braz J Morphol Sci. 2004;21(4):225-31.

3. Ichihara S, Inada Y, Nakamura T. Artificial nerve tubes and their application for repair of peripheral nerve injury: an update of current concepts. Injury. 2008;39(Suppl 4):29-39

4. Torres M, Graça D, Farias E. Reparação microcirúrgicas de nervo periférico por meio de sutura, cola de fibrina ou bainha de Biofill ${ }^{\circledR}$ em ratos Wistar. Arq Bras Med Vet Zootec. 2003;55(5):557-61.

5. Pierucci A, Faria AM, Pimentel ER, Júnior ARS, Oliveira ALR. Effects of aggrecan on schwann cell migration in vitro and nerve regeneration in vivo. Braz J Morphol Sci 2004;21(3):125-30

6. Braga Silva J, Gehlen D, Javier ARR, Menta C, Atkinson EA, Machado DC, et al. Efeitos das células-tronco adultas de medula óssea e do plasma rico em plaquetas na regeneração e recuperação funcional nervosa em um modelo de defeito agudo em nervo periférico em rato. Acta Ortop Bras. 2006;14(5):273-5.

7. Braga-Silva J, Gehlen D, Padoin AV, Machado DC, Garicochea B, Costa da Costa J. Can local supply of bone marrow mononuclear cells improve the outcome from late tubular repair of human median and ulnar nerves? J Hand Surg Eur Vol. 2008;33(4):488-93

8. Sariguney Y, Yavuzer R, Elmas C, Yenicesu I, Bolay H, Atabay K. Effect of platelet-rich plasma on peripheral nerve regeneration. J Reconstr Microsurg. 2008;24(3):159-67.

9. Gordon T, Fu SY. Long-term response to nerve injury. Adv Neurol. 1997;72:185-99.

10. Curran JM, Tang Z, Hunt JA. PLGA doping of PCL affects the plastic potential of human mesenchymal stem cells, both in the presence and absence of biological stimuli. J Biomed Mater Res A. 2009;89(1):1-12

11. Palpant NJ, Metzger JM. Aesthetic cardiology: adipose-derived stem cells for myocardial repair. Curr Stem Cell Res Ther. 2010;5(2):145-52.

12. Wakitani S, Okabe T, Horibe S, Mitsuoka T, Saito M, Koyama T, et al. Safety of autologous bone marrow-derived mesenchymal stem cell transplantation for cartilage repair in 41 patients with 45 joints followed for up to 11 years and 5 months. J Tissue Eng Regen Med. 2011;5(2):146-50.

13. Weir $\mathrm{MD}, \mathrm{Xu} \mathrm{HH}$. Human bone marrow stem cell-encapsulating calcium phosphate scaffolds for bone repair. Acta Biomater. 2010;6(10):4118-26.

14. Lemischka IR. Stem cell biology: a view toward the future. Ann NY Acad Sci. 2005; 1044:132-8.

15. Fodor WL. Tissue engineering and cell based therapies, from the bench to the clinic: the potential to replace, repair and regenerate. Reprod Biol Endocrinol. 2003;1:102.

16. Kallur T, Farr TD, Bohm-Sturm P, Kokaia Z, Hoehn M. Spatio-temporal dynamics, differentiation and viability of human neural stem cells after implantation into neonatal rat brain. Eur J Neurosci. 2011;34(3):382-93.

17. Kuznetsov SA, Mankani MH, Gronthos S, Satomura K, Bianco P, Robey PG. Circulating skeletal stem cells. J Cell Biol. 2001;153(5):1133-40.

18. Zuk PA, Zhu M, Mizuno H, Huang J, Futrell JW, Katz AJ, et al. Multilineage cells from human adipose tissue: implications for cell-based therapies. Tissue Eng. 2001;7(2):211-28.

19. Mimura T, Dezawa M, Kanno H, Sawada $H$, Yamamoto I. Peripheral nerve regeneration by transplantation of bone marrow stromal cell-derived Schwann cells in adult rats. J Neurosurg. 2004;101(5):806-12.

20. Chen X, Wang XD, Chen G, Lin WW, Yao J, Gu XS. Study of in vivo differentiation of rat bone marrow stromal cells into schwann cell-like cells. Microsurgery. 2006;26(2):111-5

21. Yang $Y$, Yuan $X$, Ding F, Yao D, Gu Y, Liu J, et al. Repair of rat sciatic nerve gap by a silk fibroin-based scaffold added with bone marrow mesenchymal stem cells. Tissue Eng Part A. 2011;17(17-18):2231-44.

22. Colomé LM, Gomes C, Crosignani N, Paz AH, Lugo AA, Guimarães KM, et al. Utilização de células-tronco autólogas de medula óssea na regeneração do nervo tibial de coelhos mediante técnica de tubulização com prótese de silicone. Ciência Rural. 2008;38(92529-2534):2529-34.

23. Goel RK, Suri V, Suri A, Sarkar C, Mohanty S, Sharma MC, et al. Effect of bone marrow-derived mononuclear cells on nerve regeneration in the transection model of the rat sciatic nerve. J Clin Neurosci. 2009;16(9):1211-7.

24. Wang J, Ding F, Gu Y, Liu J, Gu X. Bone marrow mesenchymal stem cells promote cell proliferation and neurotrophic function of Schwann cells in vitro and in vivo. Brain Res. 2009;1262:7-15.

25. di Summa PG, Kingham PJ, Raffoul W, Wiberg M, Terenghi G, Kalbermatten DF. Adipose-derived stem cells enhance peripheral nerve regeneration. J Plast Reconstr Aesthet Surg. 2010;63(9):1544-52.

26. Zhang $Y$, Luo H, Zhang Z, Lu Y, Huang X, Yang L, et al. A nerve graft constructed with xenogeneic acellular nerve matrix and autologous adipose-derived mesenchymal stem cells. Biomaterials. 2010;31(20):5312-24.

27. Rodriguez FJ, Verdu E, Ceballos D, Navarro X. Nerve guides seeded with autologous schwann cells improve nerve regeneration. Exp Neurol. 2000;161(2):571-84.

28. Zhang F, Blain B, Beck J, Zhang J, Chen Z, Chen ZW, et al. Autogenous venous graft with one-stage prepared Schwann cells as a conduit for repair of long segmental nerve defects. J Reconstr Microsurg. 2002;18(4):295-300.

29. Evans GR, Brandt K, Katz S, Chauvin P, Otto L, Bogle M, et al. Bioactive poly(L-lactic acid) conduits seeded with Schwann cells for peripheral nerve regeneration. Biomaterials. 2002;23(3):841-8.

30. Galla TJ, Vedecnik SV, Halbgewachs J, Steinmann S, Friedrich C, Stark GB. Fibrin/Schwann cell matrix in poly-epsilon-caprolactone conduits enhances guided nerve regeneration. Int J Artif Organs. 2004;27(2):127-36.

31. Koshimune M, Takamatsu K, Nakatsuka H, Inui K, Yamano Y, Ikada Y. Creating bioabsorbable Schwann cell coated conduits through tissue engineering. Biomed Mater Eng. 2003;13(3):223-9.

32. Nilsson A, Dahlin L, Lundborg G, Kanje M. Graft repair of a peripheral nerve without the sacrifice of a healthy donor nerve by the use of acutely dissociated autologous Schwann cells. Scand J Plast Reconstr Surg Hand Surg. 2005;39(1):1-6.

33. Sinis N, Schaller HE, Becker ST, Schlosshauer B, Doser M, Roesner H, et al. Long nerve gaps limit the regenerative potential of bioartificial nerve conduits filled with Schwann cells. Restor Neurol Neurosci. 2007;25(2):131-41.

34. Pfister LA, Papaloizos M, Merkle HP, Gander B. Nerve conduits and growth factor delivery in peripheral nerve repair. J Peripher Nerv Syst. 2007;12(2):65-82.

35. Guenard V, Kleitman N, Morrissey TK, Bunge RP, Aebischer P. Syngeneic Schwann cells derived from adult nerves seeded in semipermeable guidance channels enhance peripheral nerve regeneration. J Neurosci. 1992;12(9):3310-20.

36. Kim DH, Connolly SE, Kline DG, Voorhies RM, Smith A, Powell M, et al. Labeled Schwann cell transplants versus sural nerve grafts in nerve repair. J Neurosurg. 1994;80(2):254-60.

37. Sinis N, Schaller HE, Schulte-Eversum C, Schlosshauer B, Doser M, Dietz K, et al. Nerve regeneration across a $2-\mathrm{cm}$ gap in the rat median nerve using a resorbable nerve conduit filled with Schwann cells. J Neurosurg. 2005;103(6):1067-76.

38. Hoke A. Mechanisms of Disease: what factors limit the success of peripheral nerve regeneration in humans? Nat Clin Pract Neurol. 2006;2(8):448-54.

39. Pereira Lopes FR, Frattini F, Marques SA, Almeida FM, de Moura Campos LC, Langone F, et al. Transplantation of bone-marrow-derived cells into a nerve guide resulted in transdifferentiation into Schwann cells and effective regeneration of transected mouse sciatic nerve. Micron. 2010;41(7):783-90.

40. Walsh S, Midha R. Practical considerations concerning the use of stem cells for peripheral nerve repair. Neurosurg Focus. 2009;26(2):E2

41. Safford KM, Hicok KC, Safford SD, Halvorsen YD, Wilkison WO, Gimble JM, et al. Neurogenic differentiation of murine and human adipose-derived stromal cells. Biochem Biophys Res Commun. 2002;294(2):371-9.

42. Diniz $D$, Avelino $D$. International perspective on embryonic stem cell research Rev Saude Publica. 2009;43(3):541-7.

43. Lo B, Parham L. Ethical issues in stem cell research. Endocr Rev. 2009;30(3):204-13

44. Pittenger MF, Mackay AM, Beck SC, Jaiswal RK, Douglas R, Mosca JD, et al. Multilineage potential of adult human mesenchymal stem cells. Science. 1999;284(5411):143-7.

45. Abdallah BM, Kassem M. Human mesenchymal stem cells: from basic biology to clinical applications. Gene Ther. 2008;15(2):109-16.

46. Woodbury D, Schwarz EJ, Prockop DJ, Black IB. Adult rat and human bone marrow stromal cells differentiate into neurons. J Neurosci Res. 2000;61(4):364-70.

47. Dezawa M, Takahashi I, Esaki M, Takano M, Sawada $\mathrm{H}$. Sciatic nerve regeneration in rats induced by transplantation of in vitro differentiated bone-marrow stromal cells. Eur J Neurosci. 2001;14(11):1771-6.

48. Dezawa $\mathrm{M}$, Kanno $\mathrm{H}$, Hoshino $\mathrm{M}$, Cho $\mathrm{H}$, Matsumoto $\mathrm{N}$, Itokazu $\mathrm{Y}$, et al. Specific induction of neuronal cells from bone marrow stromal cells and application for autologous transplantation. J Clin Invest. 2004;113(12):1701-10.

49. Tohill M, Mantovani C, Wiberg M, Terenghi G. Rat bone marrow mesenchymal stem cells express glial markers and stimulate nerve regeneration. Neurosci Lett. 2004;362(3):200-3.

50. Dezawa M, Hoshino M, Nabeshima Y, Ide C. Marrow stromal cells: implications in health and disease in the nervous system. Curr Mol Med. 2005;5(7):723-32.

51. Keilhoff G, Goihl A, Langnase K, Fansa H, Wolf G. Transdifferentiation of mesenchymal stem cells into Schwann cell-like myelinating cells. Eur J Cell Biol. 2006;85(1):11-24.

52. Keilhoff G, Goihl A, Stang F, Wolf G, Fansa H. Peripheral nerve tissue engineering: autologous Schwann cells vs. transdifferentiated mesenchymal stem cells. Tissue Eng. 2006;12(6):1451-65.

53. Montzka K, Lassonczyk N, Tschoke B, Neuss S, Fuhrmann T, Franzen R, et al Neural differentiation potential of human bone marrow-derived mesenchymal stromal cells: misleading marker gene expression. BMC Neurosci. 2009;10:16.

54. Choi BH, Zhu SJ, Kim BY, Huh JY, Lee SH, Jung JH. Transplantation of cultured bone marrow stromal cells to improve peripheral nerve regeneration. Int J Oral Maxillofac Surg. 2005;34(5):537-42.

55. Wang D, Liu XL, Zhu JK, Jiang L, Hu J, Zhang Y, et al. Bridging small-gap peripheral nerve defects using acellular nerve allograft implanted with autologous bone marrow stromal cells in primates. Brain Res. 2008;1188:44-53.

56. Oliveira JT, Almeida FM, Biancalana A, Baptista AF, Tomaz MA, Melo PA, et al. 
Mesenchymal stem cells in a polycaprolactone conduit enhance median-nerve regeneration, prevent decrease of creatine phosphokinase levels in muscle, and improve functional recovery in mice. Neuroscience. 2010;170(4):1295-303.

57. Xu Y, Liu L, Li Y, Zhou C, Xiong F, Liu Z, et al. Myelin-forming ability of Schwann cell-like cells induced from rat adipose-derived stem cells in vitro. Brain Res. 2008;1239:49-55.

58. Zuk PA, Zhu M, Ashjian P, De Ugarte DA, Huang Jl, Mizuno H, et al. Human adipose tissue is a source of multipotent stem cells. Mol Biol Cell. 2002;13(12):4279-95.

59. Yoshimura H, Muneta T, Nimura A, Yokoyama A, Koga H, Sekiya I. Comparison of rat mesenchymal stem cells derived from bone marrow, synovium, periosteum, adipose tissue, and muscle. Cell Tissue Res. 2007;327(3):449-62.

60. Gimble JM, Katz AJ, Bunnell BA. Adipose-derived stem cells for regenerative medicine. Circ Res. 2007;100(9):1249-60.

61. Kingham PJ, Kalbermatten DF, Mahay D, Armstrong SJ, Wiberg M, Terenghi G. Adipose-derived stem cells differentiate into a Schwann cell phenotype and promote neurite outgrowth in vitro. Exp Neurol. 2007;207(2):267-74.

62. Boyd JG, Gordon T. Neurotrophic factors and their receptors in axonal regeneration and functional recovery after peripheral nerve injury. Mol Neurobiol. 2003;27(3):277-324.

63. Apfel SC, Kessler JA, Adornato BT, Litchy WJ, Sanders C, Rask CA. Recombinant human nerve growth factor in the treatment of diabetic polyneuropathy. NGF Study Group. Neurology. 1998;51(3):695-702.

64. Petruska JC, Mendell LM. The many functions of nerve growth factor: multiple actions on nociceptors. Neurosci Lett. 2004 6;361(1-3):168-71.

65. Sun W, Sun C, Lin H, Zhao H, Wang J, Ma H, et al. The effect of collagenbinding NGF-beta on the promotion of sciatic nerve regeneration in a rat sciatic nerve crush injury model. Biomaterials. 2009;30(27):4649-56.

66. Takaki M, Nakayama S, Misawa $H$, Nakagawa T, Kuniyasu $H$. In vitro formation of enteric neural network structure in a gut-like organ differentiated from mouse embryonic stem cells. Stem Cells. 2006;24(6):1414-22.

67. Geremia NM, Pettersson LM, Hasmatali JC, Hryciw T, Danielsen N, Schreyer $\mathrm{DJ}$, et al. Endogenous BDNF regulates induction of intrinsic neuronal growth programs in injured sensory neurons. Exp Neurol. 2010;223(1):128-42.

68. Sanchez-Ramos J, Song S, Cardozo-Pelaez F, Hazzi C, Stedeford T, Willing $A$, et al. Adult bone marrow stromal cells differentiate into neural cells in vitro. Exp Neurol. 2000;164(2):247-56

69. Schecterson LC, Bothwell M. Novel roles for neurotrophins are suggested by BDNF and NT-3 mRNA expression in developing neurons. Neuron. 1992;9(3):449-63.

70. Henderson CE, Phillips HS, Pollock RA, Davies AM, Lemeulle C, Armanini M, et al. GDNF: a potent survival factor for motoneurons present in peripheral nerve and muscle. Science. 1994;266(5187):1062-4.

71. Ito $Y$ Yamamoto M Li M, Doyu M, Tanaka F, Mutch $T$, et al. Differential temporal expression of mRNAs for ciliary neurotrophic factor (CNTF), leukemia inhibitory factor (LIF), interleukin-6 (IL-6), and their receptors (CNTFR alpha, LIFR beta, IL-6R alpha and gp130) in injured peripheral nerves. Brain Res. 1998;793:321-7.

72. Nakae J, Kido Y, Accili D. Distinct and overlapping functions of insulin and IGF-I receptors. Endocr Rev. 2001;22(6):818-35.

73. Apel PJ, Ma J, Callahan M, et al. Effect of locally delivered IGF-1 on nerve regeneration during aging: an experimental study in rats. Muscle Nerve. 2010;41:335-41

74. Yakar S, Wu Y, Setser J, Rosen CJ. The role of circulating IGF-I: lessons from human and animal models. Endocrine. 2002;19(3):239-48.

75. Rosenzweig SA. What's new in the IGF-binding proteins? Growth Horm IGF Res. 2004;14(5):329-36.

76. Terenghi G. Peripheral nerve injury and regeneration. Histol Histopathol. 1995;10(3):709-18.

77. Hobson MI, Green CJ, Terenghi G. VEGF enhances intraneural angiogenesis and improves nerve regeneration after axotomy. J Anat. 2000;197(Pt 4):591-605.

78. Jin KL, Mao XO, Greenberg DA. Vascular endothelial growth factor: direct neuroprotective effect in in vitro ischemia. Proc Natl Acad Sci U S A. 2000;97(18):10242-7.

79. Xu XY, Yu H, Gao SJ, Mao HQ, Leong KW, Wang S. Polyphosphoester mi- crospheres for sustained release of biologically active nerve growth factor. Biomaterials. 2002;23(17):3765-72.

80. $\mathrm{Xu} \mathrm{H}$, Yan Y, Li S. PDLLA/chondroitin sulfate/chitosan/NGF conduits for peripheral nerve regeneration. Biomaterials. 2011;32(20):4506-16.

81. Lee AC, Yu VM, Lowe JB, 3rd, Brenner MJ, Hunter DA, Mackinnon SE, et al. Controlled release of nerve growth factor enhances sciatic nerve regeneration. Exp Neurol. 2003;184(1):295-303.

82. Hoke A, Ho T, Crawford TO, LeBel C, Hilt D, Griffin JW. Glial cell line-derived neurotrophic factor alters axon schwann cell units and promotes myelination in unmyelinated nerve fibers. J Neurosci. 2003;23(2):561-7.

83. Patel M, Mao L, Wu B, VandeVord P. GDNF blended chitosan nerve guides: an in vivo study. J Biomed Mater Res A. 2009;90(1):154-65

84. Caroni P, Grandes P. Nerve sprouting in innervated adult skeletal muscle induced by exposure to elevated levels of insulin-like growth factors. J Cell Biol. 1990;110(4):1307-17.

85. Hobson MI. Increased vascularisation enhances axonal regeneration within an acellular nerve conduit. Ann R Coll Surg Engl. 2002;84(1):47-53.

86. Madison RD, da Silva C, Dikkes P, Sidman RL, Chiu TH. Peripheral nerve regeneration with entubulation repair: comparison of biodegradeable nerve guides versus polyethylene tubes and the effects of a laminin-containing gel. Exp Neurol. 1987;95(2):378-90.

87. Madison RD, Da Silva CF, Dikkes P. Entubulation repair with protein additives increases the maximum nerve gap distance successfully bridged with tubular prostheses. Brain Res. 1988 3;447(2):325-34.

88. Verdu E, Labrador RO, Rodriguez FJ, Ceballos D, Fores J, Navarro X. Alignment of collagen and laminin-containing gels improve nerve regeneration within silicone tubes. Restor Neurol Neurosci. 2002;20(5):169-79.

89. Cemil B, Ture D, Cevirgen B, Kaymaz F, Kaymaz M. Comparison of collagen biomatrix and omentum effectiveness on peripheral nerve regeneration. Neurosurg Rev. 2009;32(3):355-62.

90. Marx RE. Platelet-rich plasma (PRP): what is PRP and what is not PRP? Implant Dent. 2001;10(4):225-8.

91. Farrag TY, Lehar M, Verhaegen P, Carson KA, Byrne PJ. Effect of platelet rich plasma and fibrin sealant on facial nerve regeneration in a rat model Laryngoscope. 2007;117(1):157-65.

92. Thorwarth M, Wehrhan F, Schultze-Mosgau S, Wiltfang J, Schlegel KA. PRP modulates expression of bone matrix proteins in vivo without long-term effects on bone formation. Bone. 2006;38(1):30-40.

93. Yamamoto H, Gurney ME. Human platelets contain brain-derived neurotrophic factor. J Neurosci. 1990;10(11):3469-78.

94. Camargo PM, Lekovic V, Weinlaender M, Vasilic N, Madzarevic M, Kenney EB Platelet-rich plasma and bovine porous bone mineral combined with guided tissue regeneration in the treatment of intrabony defects in humans. J Periodontal Res. 2002;37(4):300-6.

95. Mazor Z, Peleg M, Garg AK, Luboshitz J. Platelet-rich plasma for bone graft enhancement in sinus floor augmentation with simultaneous implant placement: patient series study. Implant Dent. 2004;13(1):65-72.

96. Plachokova AS, van den Dolder J, van den Beucken JJ, Jansen JA. Bone regenerative properties of rat, goat and human platelet-rich plasma. Int J Oral Maxillofac Surg. 2009;38(8):861-9.

97. 97. Man D, Plosker H, Winland-Brown JE. The use of autologous plateletrich plasma (platelet gel) and autologous platelet-poor plasma (fibrin glue) in cosmetic surgery. Plast Reconstr Surg. 2001;107(1):229-37.

98. Uebel CO, da Silva JB, Cantarelli D, Martins P. The role of platelet plasma growth factors in male pattern baldness surgery. Plast Reconstr Surg. 2006;118(6):1458-66.

99. Kon E, Filardo G, Delcogliano M, Presti ML, Russo A, Bondi A, et al. Plateletrich plasma: new clinical application: a pilot study for treatment of jumper's knee. Injury. 2009;40(6):598-603.

100. Nin JR, Gasque GM, Azcarate AV, Beola JD, Gonzalez MH. Has platelet-rich plasma any role in anterior cruciate ligament allograft healing? Arthroscopy. 2009;25(11):1206-13.

101. Elgazzar RF, Mutabagani MA, Abdelaal SE, Sadakah AA. Platelet rich plasma may enhance peripheral nerve regeneration after cyanoacrylate reanastomosis: a controlled blind study on rats. Int J Oral Maxillofac Surg. 2008;37(8):748-55 